\title{
RANCANG BANGUN APLIKASI KATALOG ONLINE DAN SISTEM PEMESANAN PRODUK
}

\author{
Riki Harianto ${ }^{1}$, Regiolina Hayami ${ }^{2}$, Mitra Unik \\ ${ }^{123}$ Fakultas Ilmu Komputer, Universitas Muhammadiyah Riau \\ ${ }^{1}$ email: rikiharianto@student.umri.ac.id \\ email: regiolinahayami@umri.ac.id \\ 3email: mitraunik@umri.ac.id
}

\begin{abstract}
At the sale of Sahabatkoe Ponsel using printed catalogs in providing product information to consumers. The printed catalog used is very limited and the existing catalog products are not always valid so the information displayed by the catalog often does not update. With the limited number of employees and catalogs, consumers are not maximally served due to the promos that always changing and the latest products. In addition, the development of the phenomenon of online shopping has also become a serious challenge in the business process. The purpose of this research is to design a computer system that is a complete online-based information media, as an effective promotional media, as well as the ordering feature of products that order using Barcode as proof of ordering goods. Barcode used is only valid for 2 hours from the order, then the consumer pays the order directly to the store. From the results, this system can display information completely, realtime, easy to use and access so that consumers get what they are looking for, and Sahabatkoe Mobile phones can speed up the transaction process, deliver promotions appropriately, and provide maximum service to customers and can greatly increase the quantity sales.
\end{abstract}

Key Words : Online Catalogs, QRCode, Information

\begin{abstract}
Abstrak
Pada penjualan handphone Sahabatkoe Ponsel menggunakan katalog cetak dalam pemberian informasi produk kepada konsumen. Katalog cetak yang digunakan sangat terbatas dan produk yang ada dikatalog tidak selalu valid sehingga informasi yang ditampilkan katalog sering tidak update. Dengan terbatasnya karyawan dan katalog maka konsumen tidak terlayani dengan maksimal dikarenakan promo yang selalu berubah dan produk yang selalu terbaru. Selain itu berkembangnya fenomena belanja online juga menjadi tantangan berat dalam proses bisnis. Tujuan dalam penelitian ini adalah untuk merancang suatu sistem komputer yang menjadi media informasi berbasis online yang lengkap, sebagai media promosi yang efektif, serta adanya fitur pemesanan produk yang proses pemesanannya menggunakan Barcode sebagai bukti pemesanan barang. Barcode yang digunakan hanya berlaku selama 2 jam sejak pemesanan, kemudian konsumen membayar pesanannya langsung ke toko. Dari hasil penelitian bahwa sistem ini bisa menampilkan informasi dengan lengkap, realtime, mudah digunakan dan diakses sehingga konsumen mendapatkan apa yang dicari, dan Sahabatkoe Ponsel bisa mempercepat proses transaksi, menyampaikan promosi dengan tepat, dan memberikan pelayanan yang maksimal kepada pelanggannya serta sangat bisa meningkatkan kuantiti penjualan.
\end{abstract}


Kata Kunci : Katalog Online, QRCode, Informasi.

\section{PENDAHULUAN}

Pesatnya perkembangan teknologi dan informasi memberikan kemudahan bagi masyarakat untuk mendapatkan informasi yang mereka butuhkan, kini masyarakat sedang bergerak dari sistem belanja konvensional menjadi sistem online. Internet merupakan cara yang paling baik untuk saat ini karena calon konsumen tidak perlu pergi untuk melihat barangnya secara langsung namun akan ditampilkan pada web produsen, seperti halnya yang terjadi saat ini yaitu fenomena belanja online atau fenomena belanja melalui internet dimana di tanah air sekarang tumbuh subur berbagai macam E-Commerce.

Namun tidak semua semua perusahaan telah menerapkan ataupun memanfaatkan adanya E-Commerce tersebut, salah satunya adalah Sahabatkoe Ponsel. Saat ini perusahaan tersebut masih memanfaatkan sistem penjualan yang konvensional dalam hal ini pelanggan langsung ke perusahaan untuk melakukan transaksi barang dan melihat informasi produk yang dijual. pada prosesnya masih menggunakan katalog cetak dalam pemberian informasi produk ke konsumen. Katalog cetak yang digunakan sangat terbatas dan mempunyai beberapa kekurangan, yaitu katalog tidak selalu update dan selalu tertinggal karena perubahan akan produk, ketersediaan maupun harga tiap merk dan tipe handphone selalu berubah setiap harinya sesuai barang masuk, dan juga promo. Jika ada perubahan karyawan harus mencetak ulang tiap lembar kertas yang ingin dirubah dan membutuhkan waktu yang lama, dan juga memakan biaya yang terus menerus.
Selain itu setiap konsumen yang datang ingin mendapatkan informasi dari karyawan maupun media informasi yang digunakan, dikarena keterbatasan informasi yang tersedia di katalog cetak dan ketidakmampuan karyawan dalam menguasai dan menjelaskan setiap unit handphone karena cepatnya perputaran, pembaruan fitur, banyaknya merk maupun tipe handphone untuk dijelaskan kepada konsumen supaya konsumen tertarik untuk membelinya. Keterbatasan jumlah karyawan juga berpengaruh karena tidak terlayaninya dengan baik konsumen yang datang, dan juga konsumen sering tidak mengetahui promo terbaru dikarenakan katalog tidak bisa menampilkan promo secara realtime dan update, konsumen juga sering mencari barang yang dinginkan atau barang yang dicari dari rumah tidak tersedia baik dari stock maupun varian warna.

Berdasarkan permasalahan diatas yang telah penulis sampaikan, Sahabatkoe Ponsel perlu adanya suatu aplikasi media berbasis online yaitu sebagai media informasi yang lengkap serta adanya fitur pemesanan produk menggunakan Barcode ( QRCode ) sebagai metode pemesanan produk dikarenakan Sahabatkoe Ponsel yang fokus pada target konsumen didalam kota Pekanbaru, dengan adanya aplikasi tersebut diharapkan menjadi solusi Sahabatkoe ponsel dalam meningkatkan pelayanan dan memanfaatkan fitur-fitur yang diberikan sebagai media promo penjualan dan kuantiti penjualan yang meningkat. 


\section{METODE PENELITIAN}

Metode penelitian merupakan tahap untuk membangun sistem aplikasi yang dibangun, dilakukan secara berurutan. Tahapan penelitian yang diadopsi adalah Desain Instruksional (ADDIE). Model ADDIE (Analysis, Design, Development, Implementation, Evaluation) disajikan pada gambar 3.1 yang diperkenalkan oleh Rosset pada tahun 1987, merupakan model reka bentuk yang berfungsi sebagai garis panduan ke arah proses yang menyediakan sarana untuk pengambilan keputusan untuk menentukan siapa, apa, kapan, dimana, mengapa, dan bagaimana sebuah program penelitian tersebut.

Adapun langkah / tahapan dari Desain Intruksional adalah sebagai berikut:

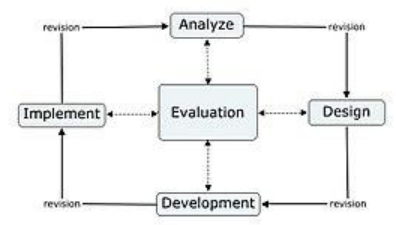

Gambar 1 Model ADDIE

(sumber:

http://www.instructionaldesign.org)

\section{A. Tahap Analisis (Analyze)}

Pada tahap analisis ini penulis melakukan kegiatan analisa setelah data dari narasumber atau sumber data lain terkumpul. Menganalisa kebutuhan dari sistem yang akan dibuat dan juga menganalisis sistem yang sudah ada sebelumnya mengidentifikasi kebutuhan sistem yang akan dibuat dengan cara menetapkan data mana yang dipakai. Dalam hal ini penulis mengumpulkan data dengan menggunakan teknik sebagai berikut:

a. Studi Pustaka
Pada tahap ini dapat mengambil bahan acuan dari sumber yaitu buku - buku, jurnal, makalah baik berasal dari perpustakaan maupun internet yang ada kaitannya dengan penulisan laporan penelitian ini. Penulis mengumpul berbagai sumber tulisan yang meliputi dokumen-dokumen tertulis yang didapat dari tempat penulis melakukan penelitian, jurnal-jurnal, karya tugas akhir serta buku-buku yang berhubungan dengan topik yang penulis angkat sebagai penelitian.

b. Wawancara

Melakukan wawancara langsung kepada pakar atau ahli dalam bidang atau menemui orang yang dianggap berkompeten terkait penelitian ini, yaitu salah satunya dengan melakukan bimbingan dengan dosen pembimbing. Penulis melakukan wawancara dengan metode tanya jawab secara lisan kepada responden yang penulis anggap berkompeten dalam menjawab pertanyaan-pertanyaan yang penulis ajukan seputar pencarian data dan alur penelitian. Wawancara, penulis lakukan ditujukan kebeberapa responden seperti pimpinan Sahabatkoe Ponsel Riau Pak Rahmat Hidayat, Pegawai Front Line / yang bertugas dalam pelayanan, dan Pegawai Administrasi yang mencetak Katalog.

c. Observasi

Mendatangi serta mengamati proses kegiatan yang berlaku di tempat penelitian. Penulis mendatangi tempat penelitian yaitu Sahabatkoe Ponsel guna mengetahui secara langsung proses / alur kegiatan yang dilakukan oleh Sahabatkoe Ponsel dalam proses kegiatan bisnisnya.

\section{B. Tahap Desain (Perancangan)}

Tahap ini dikenal dengan istilah membuat rancangan (blue print). Beberapa tahapan yang dilalui pada tahap ini adalah : 
a. Membuat gambaran umum pemodelan Standar Operasional Prosedur proses pelayanan yang terjadi di lokasi penelitian

b. Pemodelan Sistem

Pada tahapan perancangan aplikasi ini, penulis menggunakan UML (Unified Modeling Language) sebagai alat bantu (tools).

c. Perancangan database

Pada tahap ini penulis melakukan perancangan terhadap tabel-tabel database yang akan digunakan dalam sistem.

d. Perancangan Antarmuka

Pada tahap ini penulis melakukan perancangan antarmuka sistem, perancangan yang dilakukan meliputi halaman-halaman yang ada dalam sistem.

\section{Tahap Pengembangan \\ (Develompment)}

Setelah melakukan tahapan desain maka didapat gambaran umum keseluruhan proses penelitian dan sistem yang akan dibuat, selanjutnya penulis membuat sebuah Aplikasi Katalog Online Berbasis Web Sebagai Media Promosi, Informasi dan Pemesanan Produk dengan menggabungkan fungsi-fungsi otomatisasi pada sistem yang akan dibuat.

\section{Tahap Implementasi \\ (Implementation)}

Merupakan tahap penerjemah hasil analisa kedalam bentuk pengkodean sesuai dengan hasil perancangan sistem yang dibuat. Bahasa pemprograman yang digunakan adalah bahasa PHP dan MySQL.

\section{E. Tahap Evaluasi (Evaluation)}

Evaluasi adalah proses untuk melihat apakah sistem yang sedang dibangun berhasil, sesuai dengan harapan awal atau tidak. Tahap evaluasi bisa dilakukan pada setiap tahap diatas yang disebut evaluasi formatif, karena tujuannya untuk kebutuhan revisi.
Pada evaluasi sistem / pengujian akan digunakan metode Alpha dan Beta testing, yaitu Melakukan pengujian berdasarkan apa yang dilihat, fokus terhadap fungsionalitas output dan juga penerapan langsung aplikasi serta pengaruh dari implementasi aplikasi.

\section{HASIL DAN PEMBAHASAN}

\section{Pembahasan}

A. Tampilan Halaman Utama

Halaman Utama menampilkan Data Statistik dan grafik bulanan yang bisa diunduh oleh Admin maupun kasir.

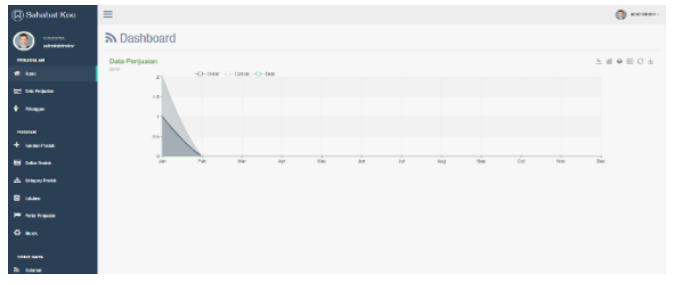

\section{Gambar 2 Tampilan Halaman Utama}

\section{B. Tampilan Data Transaksi}

Pada Halaman data Transaksi Admin dan Kasir dapat melihat data penjualan seperti transaksi yang sudah selesai, transaksi yang batal, dan melihat pesanan baru serta mengkonfirmasinya.

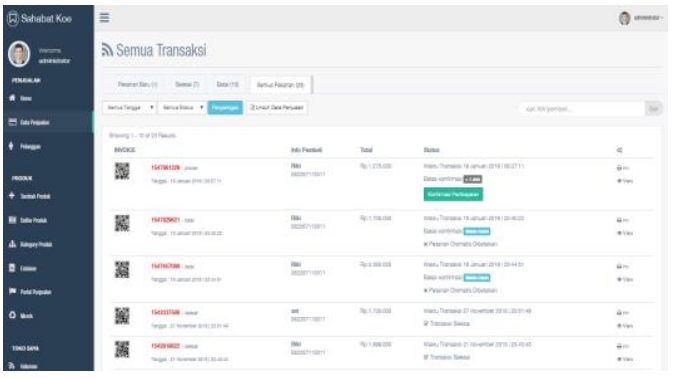

\section{Gambar 3 Tampilan Data Transaksi}

\section{Tampilan Data Produk}

Pada halaman Data Produk, admin dapat menginput data-data apa yang dibutuhkan dalam menginput data Produk, berikut tampilan data Produk yang telah diinput. 


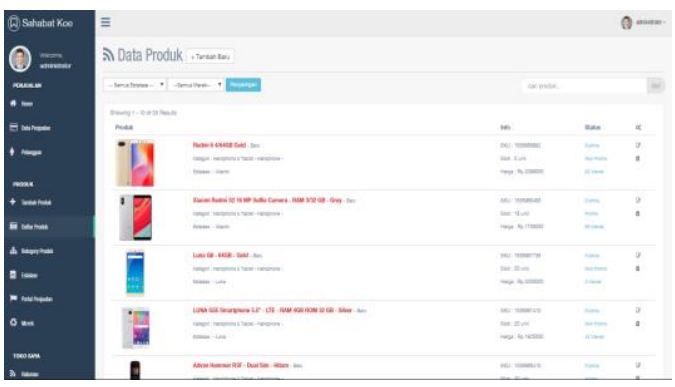

Gambar 4 Tampilan Data Produk

D. Tampilan Halam User Interface Konsumen

Pada Halaman User Interface konsumen, Konsumen dapat melihat berbagai macam informasi yang disampaikan oleh toko, seperti Informasi Promo, kategori barang yang disediakan, barang yang baru masuk, serta berbagai barang yang dijual dan informasi lainnya, berikut tampilannya.

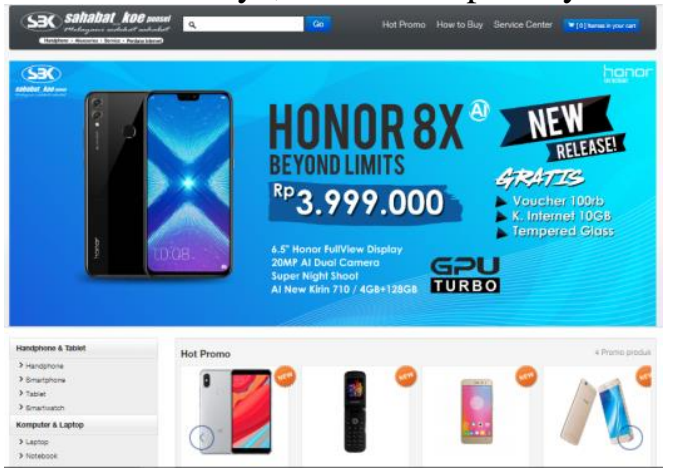

\section{Gambar 5 Tampilan User Interface Konsumen}

E. Tampilan Detail Produk Konsumen

Pada rancangan tampilan produk konsumen, konsumen dapat melihat berbagai macam merk yang dijual oleh toko, berikut tampilannya.

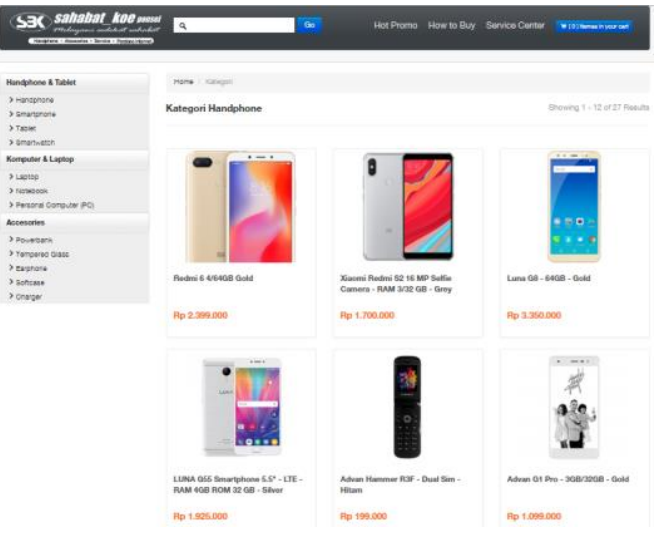

\section{Gambar 6 Tampilan Detail Produk Konsumen}

F. Halam Invoice dan Invoice transaksi penjualan

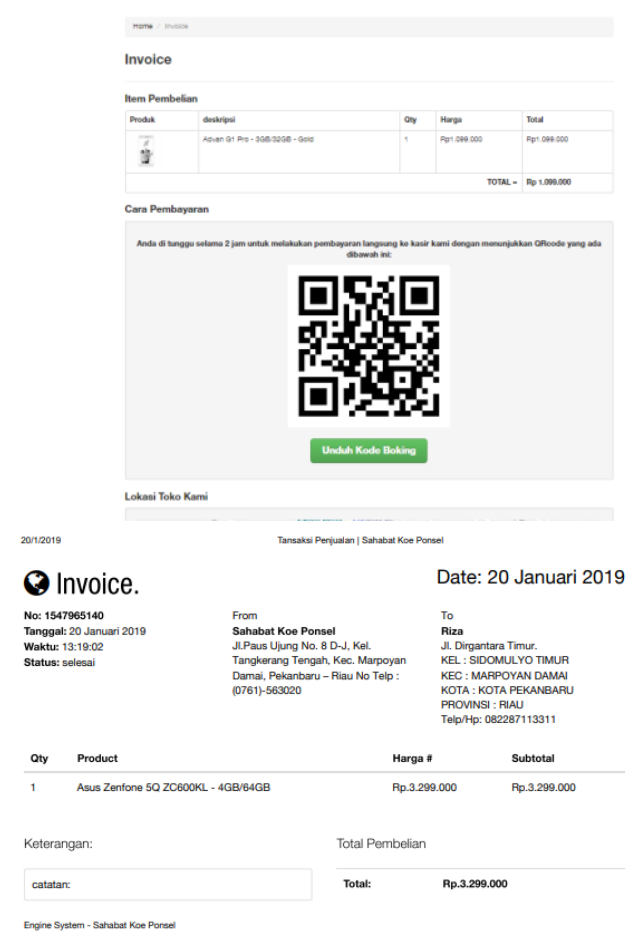

Gambar 7 Tampilan Invoice dan Invoice transaksi Penjualan

\section{Hasil}


Pengujian sistem ini menggunakan metode Alpha dan Beta yang dilakukan untuk mengetahui sistematika penggunaan sistem sudah sesuai atau tidak dan juga pengujian langsung dilapangan apakah hasil yang diinginkan sudah sesuai dengan rumusan masalah, berikut adalah hasil pengujian system :

\section{A. Pengujian Alpha}

Sebuah program diterapkan di instansi, maka program harus bebas dari kesalahan-kesalahan atau error. Oleh karena itu, program harus diuji coba terlebih dahulu untuk menemukan kesalahan kesalahan yang mungkin terjadi, pengujian ini menggunakan metode pengujian black box.

Pengujian Black box berfokus persyaratan fungsionalitas perangkat lunak. Pengujian ini berusaha menemukan kesalahan antara lain :

1. Fungsi-fungsi yang tidak benar atau hilang

2. Kesalahan interface

3. Kesalahan dalam struktur data

4. Kesalahan kinerja

Berdasarkan hasil dari pengujian Alpha yang telah dilakukan, menunjukkan bahwa aplikasi yang dibangun sudah memenuhi persyaratan fungsional. Akan tetapi, pada prosesnya masih memungkinkan untuk terjadi kesalahan. Secara fungsional sistem yang telah dibangun sudah dapat menghasilkan keluaran yang diharapkan.

\section{B. Pengujian Beta}

Pengujian Beta merupakan pengujian yang dilakukan secara objektif dimana diuji secara langsung di lapangan, user langsung bisa mengakses aplikasi di www.sahabatkoe.com, peneliti langsung mencoba menerapkan sistem di lapangan dan juga membuat kuesioner mengenai kepuasan user, untuk selanjutnya dibagikan kepada sebagian user dengan mengambil sampel sebanyak 15 orang yaitu terdiri dari 1 orang owner, 7 orang karyawan dan, 7 orang konsumen.

Kuesioner owner terdiri dari 16 pertanyaan ( Kuesioner dilampirkan ) dengan jawaban tanggapan Ya atau Tidak dengan sisi penilaian terdiri dari 4 aspek yaitu :

1. Kemudahan dalam menggunakan sistem

2. Kualitas Sistem,

3. Kualitas Informasi,

4. Penilaian dari Sistem

Berikut hasil pengujian oleh Owner :

Tabel. 1 Tabel Pengujian Konsumen

\begin{tabular}{|c|c|c|c|c|c|c|c|c|c|c|c|c|c|c|c|c|}
\hline No. Kuoesioner & 1 & 2 & 3 & 4 & 5 & 6 & 7 & 8 & 9 & 10 & 11 & 12 & 13 & 14 & 15 & 16 \\
\hline Y & $\checkmark$ & $\checkmark$ & $\checkmark$ & $\checkmark$ & $\checkmark$ & $\checkmark$ & $\checkmark$ & $\checkmark$ & $\checkmark$ & $\checkmark$ & $\checkmark$ & $\checkmark$ & $\checkmark$ & $\checkmark$ & $\checkmark$ & $\checkmark$ \\
\hline T & & & & & & & & & & & & & & & & \\
\hline
\end{tabular}

Untuk Kuesioner Konsumen terdiri dari 13 pertanyaan ( Kuesioner dilampirkan ) dengan jawab tanggapan Ya atau Tidak dengan sisi penilaian terdiri dari 4 aspek yaitu :

1. Pelayanan,

2. Kualitas Sistem,

3. Kualitas Informasi,

4. Penilaian Sistem.

Dari hasil Kuesioner yang telah diisi didapat bahwa :

Tabel. 2 Tabel Pengujian Konsumen

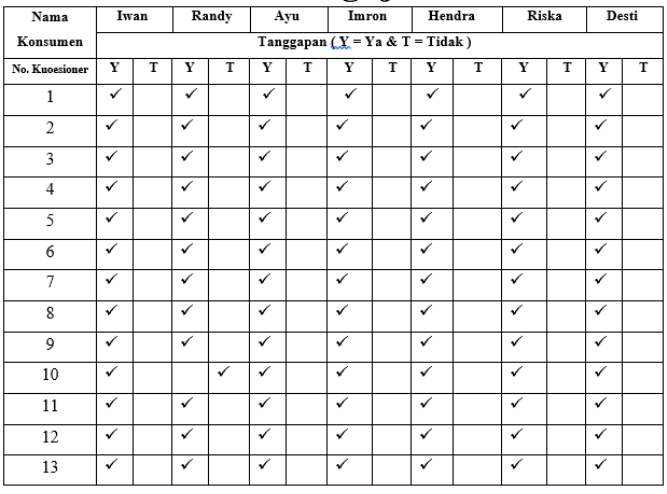

Untuk Kuesioner Karyawan terdiri dari 14 pertanyaan ( Kuesioner dilampirkan 
) dengan jawab tanggapan Ya atau Tidak dengan sisi penilaian terdiri dari 4 aspek yaitu :

1. Kumudahan,

2. Kualitas Sistem,

3. Kualitas Informasi,

4. Penilaian Sistem.

Dari hasil Kuesioner yang telah diisi didapat bahwa :

Tabel. 3 Tabel Pengujian Karyawan

\begin{tabular}{|c|c|c|c|c|c|c|c|c|c|c|c|c|c|c|}
\hline \multirow{3}{*}{$\begin{array}{c}\text { Nama } \\
\text { Karyawan } \\
\text { No. Kuoesioner }\end{array}$} & \multicolumn{2}{|c|}{ Sri N } & \multicolumn{2}{|c|}{ Syofra R } & \multicolumn{2}{|c|}{ Ronny } & \multicolumn{2}{|c|}{ Atika } & \multicolumn{2}{|c|}{ Ridho $P$} & \multicolumn{2}{|c|}{ Yopi Y } & \multicolumn{2}{|c|}{ Nanda } \\
\hline & & & & & Tang & tapar & W $=1$ & $a \& 1$ & $=$ Tida & & & & & \\
\hline & $\mathbf{Y}$ & $\mathrm{T}$ & $\mathbf{Y}$ & $\mathrm{T}$ & $\mathbf{Y}$ & $\mathrm{T}$ & $\mathbf{Y}$ & $\mathrm{T}$ & $\mathbf{Y}$ & $\mathrm{T}$ & $\mathbf{Y}$ & $\mathrm{T}$ & $\mathbf{Y}$ & $\mathrm{T}$ \\
\hline 1 & $\checkmark$ & & $\checkmark$ & & $\checkmark$ & & $\checkmark$ & & $\checkmark$ & & 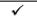 & & 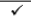 & \\
\hline 2 & $\checkmark$ & & 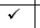 & & $\checkmark$ & & $\checkmark$ & & $\checkmark$ & & $\checkmark$ & & $\checkmark$ & \\
\hline 3 & $\checkmark$ & & $\checkmark$ & & $\checkmark$ & & $\checkmark$ & & $\checkmark$ & & $\checkmark$ & & $\checkmark$ & \\
\hline 4 & v & & $\checkmark$ & & $\checkmark$ & & $\checkmark$ & & $\checkmark$ & & $\checkmark$ & & $\checkmark$ & \\
\hline 5 & 2 & & $\checkmark$ & & $\checkmark$ & & $\checkmark$ & & $\checkmark$ & & $\checkmark$ & & $\checkmark$ & \\
\hline 6 & $\checkmark$ & & $\checkmark$ & & $\checkmark$ & & $\checkmark$ & & $\checkmark$ & & $\checkmark$ & & $\checkmark$ & \\
\hline 7 & $\checkmark$ & & $\checkmark$ & & $\checkmark$ & & $\checkmark$ & & $\checkmark$ & & $\checkmark$ & & 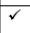 & \\
\hline 8 & 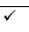 & & $\checkmark$ & & $\checkmark$ & & $\checkmark$ & & $\checkmark$ & & $\checkmark$ & & r & \\
\hline 9 & $\checkmark$ & & $\checkmark$ & & $\checkmark$ & & $\checkmark$ & & $\checkmark$ & & $\checkmark$ & & $\checkmark r$ & \\
\hline 10 & 2 & & $\checkmark$ & & $\checkmark$ & & $\checkmark$ & & $\checkmark$ & & $\checkmark$ & & 2 & \\
\hline 11 & $\checkmark$ & & $\checkmark$ & & $\checkmark$ & & $\checkmark$ & & r & & $\checkmark$ & & 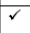 & \\
\hline 12 & $\checkmark$ & & $\checkmark$ & & $\checkmark$ & & $\checkmark$ & & r & & $\checkmark$ & & $\checkmark$ & \\
\hline 13 & $\checkmark$ & & $\checkmark$ & & $\checkmark$ & & $\checkmark$ & & 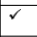 & & $\checkmark$ & & v & \\
\hline 14 & $\checkmark$ & & $\checkmark$ & & 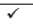 & & $\checkmark$ & & v & & $\checkmark$ & & $\checkmark$ & \\
\hline
\end{tabular}

Dari pengujian beta yang telah dilakukan yaitu dengan pengujian mengisi kuisioner yang telah dibagikan dilapangan didapat kesimpulan bahwa perangkat lunak yang telah dibangun mudah digunakan, memiliki informasi yang lengkap, dan dengan fitur pemesanan produk yang telah dicoba bahwa bisa meningkatkan pelayanan serta kuantiti dari penjualan.

\section{SIMPULAN DAN SARAN}

\section{Kesimpulan}

Berikut ini merupakan kesimpulan dari proses perancangan, implementasi, dan uji coba terhadap sistem yang dibuat. Kesimpulan yang dapat diambil adalah sistem telah dapat dibangun berbasis Online dan menyediakan informasi lengkap, serta adanya fitur pemesanan produk yang bisa meningkatkan pelayanan serta kuantiti penjualan.

\section{Saran}

Adapun beberapa saran yang dapat penulis berikan untuk penelitian lebih lanjut mengenai penelitian ini, yaitu:

1. Perlu ditambahkan fitur chat realtime sebagai media komunikasi antara pelanggan atau konsumen dan pihak toko.

2. Perlu ditambahkan fitur pembelian pulsa sehingga konsumen akan dimanjakan dengan semua transaksi berkenaan dengan smartphone mereka hanya toko Sahabatkoe Ponsel

3. Dikarenakan Sahabatkoe Ponsel menyediakan member konsumen yang telah berjalan, member yang telah ada di singkronisasikan dengan Aplikasi, sehingga bisa disediakan fitur daftar akun bagi konsumen.

\section{TERIMAKASIH}

Penulis banyak mendapatkan bantuan dan dorongan serta kemudahan dari berbagai pihak, oleh karena itu dalam kesempatan ini penulis ingin menyampaikan rasa terima kasih yang tidak terhingga kepada :

1. Bapak Dr. Mubarak, M.Si selaku Rektor Universitas Muhammadiyah Riau

2. Bapak Harun Muktar, S.Kom., M.Kom selaku Dekan Fakultas Ilmu Komputer

3. Bapak Mitra Unik, S.Kom., M.Kom selaku Ketua Program Studi Teknik Informatika Fakultas Ilmu Komputer dan sekaligus Dosen Pembimbing 2 yang telah banyak membantu dalam penulisan skripsi

4. Ibu Regiolina Hayami, S.T., M.Kom selaku Dosen Pembimbing 1 yang telah banyak membantu dalam penulisan skripsi ini 
5. Seluruh Dosen Teknik Informatika Universitas Muhammadiyah Riau yang telah memberikan banyak ilmu pengetahuan yang sangat berharga bagi penulis

6. Seluruh keluarga dan sahabat yang mendukung dalam penyelesaian laporan tugas akhir ini serta kepada seluruh pihak yang memberikan dukungan yang tidak dapat penulis sebutkan satu persatu.

Semoga Allah Subhanahu wa Ta'ala memberikan balasan yang berlipat ganda pada semuanya. Demi perbaikan selanjutnya, saran dan kritik yang membangun akan penulis terima dengan senang hati. Akhirnya hanya kepada Allah Subhanahu wa Ta'ala penulis serahkan segalanya, mudah - mudahan dapat bermanfaat khususnya bagi penulis umumnya bagi kita semua.

\section{DAFTAR PUSTAKA}

[1]. Andria, Sugiharto S. (2016). "Perencanaan Strategi Pemasaran dalam Mempertahankan dan Mengembangkan Bisnis Toko Agung di Kota Tanjung Selor, Kalimantan Utara", Surabaya : Program Manajemen Bisnis, Program Studi Manajemen, Universitas Kristen Petra. Agora Vol. 4, No. 2.

[2]. Daulay, Sere S dan Widyaiswara. (2014). Hubungan Barcode dengan Produk Industri Sebagai Standar Perdagangan Produk Industri Masa Kini. Vol.2, No.1. ISSN:2301-6523

[3]. Edhy Sutanta. (2011) Basis Data dalam Tinjuaan Konseptual. Yogyakarta: Penerbit ANDI.

[4]. Evander, M. (2015). "Penerapan Aplikasi Pembacaan Barcode menggunakan Zxing dan SOAP WebService untuk pemesanan produk berbasis Mobile". Artikel
Ilmiah, Salatiga : Fakultas Teknologi Informasi, Program Studi Teknik Informatika, Universitas Kristen Satya Wacana Salatiga.

[5]. Fithri D L ., Dkk (2017) "Pemanfaatan E-Commerce Populer Untuk Optimalisasi Pemasaran Produk Pada KUB Bordir Kurnai Kudus". Jurnal SIMETRIS, Kudus : Fakultas Teknik, Program Studi Sistem Informasi.

[6]. Handayani, Sri Peni Mugi. (2013) "Pembuatan Website E-Commerce Pada Distro Java Trend". Seminar Riset Unggulan Nasional Informatika dan Komputer FTI UNSA 2013. Vol 2 No 1. Hal.20

[7]. Hastanti (2013) "Sistem Penjualan Berbasis WEB (E-Commerce) pada Tata Distro Kabupaten Pacitan" Jurnal IJCSS - Indonesian Jurnal On Computer Science - Speed - FTI UNSA (ISSN:1979-9330)

[8]. Hitt. Michael A., Irelan. R Duane, Hoskisson. Robert E. (2013). Strategic Management Concepts and Cases Competitiveness and Glovalization ( $10^{\text {th }}$ Edition). Strayer University

[9]. Izzah. Kusuma (2016) "Pembuatan Katalog Online Layanan Jasa Berbasis WEB Sebagai Media Periklanan Penyedia Layanan Jasa" Jurnal Pengabdian Masyarat JDINAMIKA (P-ISSN:2503-1031), (e-ISSN 2503-1112)

[10]. Kadir, Abdul. "Membuat Aplikasi Web dengan PHP dan Database $M y S Q L$, Andi Offset Yogyakarta, 2009

[11]. Komputer, W. (2014) Mudah Membuat Aplikasi SMS Gatway dengan CodeIgniter. PT Elex Media Komputindo.

[12]. Kosasi, S (2014) "Pembuatan Sistem Informasi Penjualan Berbasis WEB untuk Memperluas Pangsa Pasar" 
Jurnal Prosiding SNATIF ke-1 Tahun 2014 (ISBN:978-602 119004-4)

[13]. Kosasi, S (2015) "Perancangan Sistem Informasi Penjualan Berbasis WEB dalam Memasakan Mobil Bekas" Jurnal Citec Journal (ISSN:2354-5771)

[14]. Kotler \& Keller. (2012). Marketing Management (14 ${ }^{\text {th }}$ Edition). New Jersey : Prentice Hall

[15]. Marjito, Tesaria. (2016) "Aplikasi Penjualan Online Berbasis Android (Studi Kasus : Di toko Hoax Merch) ". Jurnal Computech \& Bisnis, Vol. 10, No. 1. Hal 42.

[16]. Madcoms (2011) Aplikasi Database dengan Dreamweaver dan PHP$M y S Q L$. Edited by Andi. Yogyakarta.

[17]. Mukaromah S dan Rosadi. (2015) "Perancangan Aplikasi E-Commerce (Studi Kasus:Distributor Coklat Bandung)". Jurnal Skripsi. Bandung : STMIK Mardira Indonesia.

[18]. Muqorobin dan Sulartopo. (2014) "Perancangan Media Promosi dan Informasi Berbasis Multimedia Interaktif Pada CV. Karunia Semarang". Jurnal Skripsi. Semarang : Komputer Grafis Sekolah Tinggi Elektronika dan Komputer.

[19]. Octafian, D. T. (2015) "Web Multi Ecommerce Berbasis Framework CodeIgniter", 5(1), pp. 1-22.

[20]. Pearce, A. John., \& Robinson, B. Richard. (2013). Manajemen Strategis : Formulasi, Implementasi, dan Pengendalian. Jakatra : Salemba Empat
[21]. Prasetio, A. (2012). Buku Pintar Pemrograman Web. Mediakita. Jakarta

[22]. Yusup P, Subekti P (2010) Teori \& Praktik Penelusuran Informasi ( Information Retrieval ) Jakarta. Kencana. 216

[23]. Riyanto (2011) Membuat Sendiri Alikasi E-commerce Dengan PHP \& MySql Menggunakan Codeigniter \& JQuery.

[24]. Shalahuddin, M. and A. S, R. (2015) Rekayasa Perangkat Lunak Terstruktur dan Berorientasi Objek. 3rd edn. Bandung: Informatika.

[25]. Sofian, S. (2017) Penerapan Sistem Informasi E-Commerce Berbasis Web (Studi Kasus Untuk Vendor Pernikahan). Jurnal Skripsi. Medan: Manajemen STMB Mutli Smart.

[26]. Tominanto. (2010). Card Elektrik (Barcode) Sebagai Sistem Komputerisasi Rekam Medis di Rumah Sakit Medika Mulya Wonogiri. Vol. 1., No. 1. ISSN: 2086-2628.

[27]. Wahyutama, F., dkk. (2013). Penggunaan Teknologi Augmented Reality Berbasis Barcode sebagai Sarana Penyampaian Informasi dan Harga Barang yang Interaktif Berbasis Android, Studi Kasus pad aToko Elektronik ABC Surabaya. Vol.2, No.3 (ISSN:2337-3539).

[28]. Yuliansyah, H. (2014) "Perancangan Replika Basis Data MySQL Dengan Mekanisme Pengamanan Menggunakan SSL Encryption". 8(1), pp. 826-836. 